\title{
Growth and carcass traits associated with GH1/Alu I and POU1F1/Hinf I gene polymorphisms in Zebu and crossbred beef cattle
}

\author{
Rogério A. Curi ${ }^{1}$, Darío A. Palmieri ${ }^{1}$, Liliane Suguisawa ${ }^{2}$, Henrique N. de Oliveira ${ }^{2}$, \\ Antonio C. Silveira $^{2}$ and Catalina R. Lopes ${ }^{1}$ \\ ${ }^{1}$ Universidade Estadual Paulista 'Júlio de Mesquita Filho', Instituto de Biociências, \\ Departamento de Genética, Botucatu, SP, Brasil. \\ ${ }^{2}$ Universidade Estadual Paulista 'Júlio de Mesquita Filho', Faculdade de Medicina Veterinária \\ e Zootecnia, Departamento de Melhoramento Zootécnico e Nutrição Animal, Botucatu, SP, Brasil.
}

\begin{abstract}
The objectives of the present study were to estimate the allele and genotype frequencies of the $\mathrm{GH} / \mathrm{Alu} \mathrm{I}$ and POU1F1/Hinf I polymorphisms in beef cattle belonging to different genetic groups and to determine the effects of these polymorphisms on growth and carcass traits in cattle submitted to feedlot management, an intensive production model. Genotyping was performed on 384 animals, including 79 Nellore, 30 Canchim (5/8 Charolais + 3/8 Zebu), 30 Simmental x Nellore crossbred and 245 Angus x Nellore crossbred cattle. Body weight, weight gain, dressing percentage, Longissimus dorsi area and backfat thickness were fitted using the General Linear Model (GLM) procedure of the SAS program and the least square means of the genotypes were compared using the $F$ test. The results showed significant associations between the LL genotype of the GH1/Alu I polymorphism and higher weight gain and body weight at slaughter $(\mathrm{p}<0.05)$. The POU1F1/Hinf I polymorphism did not have any effect on the growth and carcass traits analyzed.
\end{abstract}

Key words: beef cattle, polymorphisms, candidate gene, growth, carcass.

Received: December 2, 2004; Accepted: July 5, 2005.

\section{Introduction}

Most traits of economic interest are of a quantitative nature and are controlled by a large number of genes which each contribute a small effect to the trait, the loci responsible for such traits being known as quantitative trait loci (QTL). However, there is debate regarding the existence of principal genes which contribute more to the phenotypic variation of a quantitative trait. Weight gain, feed efficiency, meat tenderness, marbling fat and backfat are some of the main quantitative traits evaluated in beef cattle bulls, although these analyses have been performed with little knowledge about the genetic and biochemical bases of these traits.

During the various growth phases of ruminants with different frame sizes differences in metabolism have been observed, somatotrophic axis hormones being a very important factor in such differences (Owens et al., 1993). The

Send correspondence to Rogério A. Curi. Universidade Estadual Paulista 'Júlio de Mesquita Filho', Faculdade de Medicina Veterinária e Zootecnia, Departamento de Melhoramento Zootécnico e Nutrição Animal, 18.618-000 Botucatu, SP, Brazil. E-mail: rogcuri@btu.flash.tv.br. somatotrophic axis play a key role in the regulation of the metabolism and physiology of mammalian growth and essentially consists of growth hormone (GH), insulin-like growth factors 1 and 2 (IGF-1 and IGF-2) and their associated binding proteins (BP) and receptors (R), i.e. IGFBP, GHR, IGF-1R and IGF-2R.

The GH1 gene codifies for circulating growth hormone which binds to the extracellular domain of specific transmembrane growth hormone receptors (GHR) which are expressed in various tissues, especially liver-tissue. This process is the signal for a cascade of intracellular metabolic events culminating in the production of IGF-1 by the target tissues, of which liver-tissue is the most important (Renaville et al., 2002).

Directly or indirectly, through the action of IGF-1, growth hormone is the main regulator of postnatal somatic growth, stimulating anabolic processes such as cell division, skeletal growth and protein synthesis. In addition, growth hormone is involved in the regulation of fat oxidation (lipolytic activity), inhibition of glucose transport to peripheral tissues (diabetogenic activity) and the regulation of the activity of ribosomes involved in the translation, which in turn influences protein synthesis (Goodman, 
1993). These processes are directly implicated in the metabolism of nutrient distribution to different tissues and, consequently, in carcass composition and quality (Schlee et al., 1994a). The growth hormone factor 1 gene (POU1F1) can be considered a candidate gene for growth and carcass traits in cattle since its product, a pituitary-specific positive transcription factor 1, regulates the transcription of $\mathrm{GH} 1$ and the prolactin gene in the mammalian anterior pituitary (Bodner et al., 1988). Pituitary-specific positive transcription factor 1 was subsequently characterized as an activator of other pituitary genes, including POU1F1 itself (Chen et al., 1990) and the growth hormone releasing hormone gene $(G H R H)$, among others (Lin et al., 1992).

Lucy et al. (1991) described a C $\rightarrow \mathrm{G}$ exchange at codon 127 in the bovine GH1 gene (GH1/Alu I polymorphism) leading to a leucine ( $L$ allele) to valine ( $V$ allele) substitution which have been associated with several production traits in cattle such as growth and carcass composition and quality (Schlee et al., 1994a, b; Regitano et al., 1999; Sartore and Di Stasio, 2000). Moody et al. (1995) identified in bovines the $A$ and $B$ alleles of the POU1F1/Hinf I polymorphism, which is an exon $6 \mathrm{~A} \rightarrow \mathrm{G}$ silent mutation of the bovine POU1F1 gene (Dierkes et al., 1998) which probably is not the direct responsible by phenotypic variation, although relationships have been observed between $P O U 1 F 1$ polymorphisms and body weight and somatic measures (Renaville et al., 1997), weaning and yearling weight (Carrijo et al., 2003).

The objectives of the present study were to estimate the allele and genotype frequencies of the different alleles of the GH1/Alu I and POU1F1/Hinf I polymorphisms of beef cattle belonging to different genetic groups and to determine associations between these polymorphisms and the performance of the animals when submitted to an intensive production model.

\section{Material and Methods}

\section{Cattle}

The study was carried out in the experimental feedlot facility of the Animal Science Department of São Paulo State University (Unesp, Botucatu-SP, Brazil) during three consecutive years $(2000=$ feedlot $1,2001=$ feedlot 2 and 2002 = feedlot 3 ) using samples of cattle from commercial herds belonging to six different farms. The sample group consisted of 384 bull calves belonging to four different genetic groups differing in frame size, these groups being $B o s$ indicus (Zebu) Nellore pure-bred cattle $(\mathrm{n}=79)$ and Bos taurus (European)/Zebu cross-breeds consisting of Canchim cattle $(5 / 8$ Charolais $+3 / 8 \mathrm{Zebu}, \mathrm{n}=30)$ and $1 / 2$ Simmental $(n=30)$ and $1 / 2$ Angus $(n=245)$ cross-breeds resulting from crosses between Simmental or Angus sires and Nellore dams.

The bull calves were weaned at 210 days using a creep-feeding system. At the beginning of the experiment the bulls were individually identified, treated against endoand ectoparasites, divided into groups of five animals in each feedlot pen according to breed, where they were fed diets formulated according to the norms of the National Research Council (NRC, 1996) for an average daily gain in excess of $1.2 \mathrm{~kg}$. After entering the pen, the bulls were allowed to adapt for about 20 days. When they were slightly over one year old, and after an average feedlot (fattening) period of 110 days, the bulls were slaughtered at a commercial abattoir.

For growth traits the bulls were weighed to assess their body weight $(\mathrm{BW})$ when first penned $\left(\mathrm{BW}_{0}\right)$ and also at the beginning of their feedlot period $\left(\mathrm{BW}_{1}\right)$ and close to the time of slaughter $\left(\mathrm{BW}_{\mathrm{END}}\right)$. Average daily weight gain (ADWG) was calculated for the interval between the last two weight measurements. For carcass traits, ribeye area (REA) or Longissimus dorsi area and backfat thickness (BT) were assessed at $\mathrm{BW}_{\mathrm{END}}$ by ultrasonography using the method of Perkins as modified by Gresham (1998) and carcass weight $(\mathrm{CW})$ was measured at slaughter with dressing percentage (DP) being taken as $\mathrm{CW}$ divided by $\mathrm{BW}$ END.

\section{Extraction of DNA and genotyping}

For each bull, $5 \mathrm{~mL}$ of total blood was collected from the left jugular vein using vacuum tubes containing $7.5 \mathrm{mg}$ of EDTA and genomic DNA extracted from a $300-\mu \mathrm{L}$ aliquot using the Genomic Prep ${ }^{\mathrm{TM}}$ Blood DNA Isolation kit according to the manufacturer's instructions (Amersham Biosciences, Piscataway, NJ, USA).

Bulls were genotyped for the GH1 and POUIF1 genes by using the polymerase chain reaction and restriction fragment length polymorphism (PCR-RFLP). The chromosome 19 GH1/Alu I forward primer was 5'-GCT GCT CCT GAG GGC CCT-3' and the reverse primer 5'-GCG GCG GCA CTT CAT GAC CCT-3' and the annealing temperature $58{ }^{\circ} \mathrm{C}$ while the chromosome 1 POU1F1/Hinf I forward primer was 5'-CAA TGA GAA AGT TGG TGC-3' and the reverse primer 5'-TCT GCA TTC GAG ATG CTC -3'with an annealing temperature of $54{ }^{\circ} \mathrm{C}$.

To determine the $G H 1$ gene $L$ and $V$ alleles we amplified a 223-bp fragment located between intron 4 and exon 5 and digested it with the $A l u$ I restriction enzyme (Schlee et al., 1994a). The POU1F1 gene $A$ and $B$ alleles were identified by amplification of a 1301-bp sequence corresponding to fragments of exons 5 and 6 followed by digestion with Hinf I (Moody et al., 1995).

Each PCR was performed in $25 \mu \mathrm{L}$ of amplification mixture consisting of $50 \mathrm{ng}$ genomic DNA, $0.20 \mu \mathrm{M}$ of each primer, $10 \mathrm{mM}$ Tris- $\mathrm{HCl}, \mathrm{pH} 8.0,50 \mathrm{mM} \mathrm{KCl}$, $2.0 \mathrm{mM} \mathrm{MgCl}_{2}, 0.2 \mathrm{mM}$ of each dNTP and 1 unit of Taq DNA polymerase. The amplification protocol was initial double- strand denaturation at $94{ }^{\circ} \mathrm{C}$ for $4 \mathrm{~min}$, followed by denaturation at $94{ }^{\circ} \mathrm{C}$ for $1 \mathrm{~min}$, primer annealing at 54 to $58^{\circ} \mathrm{C}$ for $45 \mathrm{~s}$ (depending on the primer), extension at $72^{\circ} \mathrm{C}$ 
for $1 \mathrm{~min}$, a final extension at $72{ }^{\circ} \mathrm{C}$ for $4 \mathrm{~min}$. Steps 2,3 and 4 , corresponding to one cycle, were repeated 35 times. The amplified fragments were digested in a reaction mixture containing $10 \mu \mathrm{L}$ of PCR product and 3 units of the restriction enzyme and the digested fragments separated by $3 \%$ $(\mathrm{w} / \mathrm{v})$ agarose gel horizontal electrophoresis using a 100 base pair (bp) molecular weight standard (Invitrogen, São Paulo, SP, Brazil) to calculate the size of the amplified and digested fragments which were visualized by ethidium bromide staining and exposure to ultraviolet light. The genotypes of the individual cattle were determined for each polymorphism by analyzing the size of the fragments reported as base pairs.

\section{Statistical analysis}

Genotype and allele frequencies were calculated for each polymorphism according to Weir (1996). Differences in the allele frequencies of the polymorphisms within and between genetic groups were determined by the method of Goodman adapted by Curi and Moraes (1981).

The traits of interest were analyzed by least square analysis of variance $(\mathrm{p}=0.05)$ using the General Linear Model (GLM) procedure of the SAS program (Statistical Analysis System, 1999). The linear model used to fit the quantitative variables included, in addition to the genotype effect, the contemporary group effect which considered the interaction between genetic groups $(1, \ldots, 4)$, feedlots $(1, \ldots$, $3)$ and farms of origin $(1, \ldots, 6)$ as follows: $Y_{i j k}=\mu+G_{i}+$ $\mathrm{GC}_{j}+\mathrm{e}_{i j k}$, where $\mathrm{Y}_{i j k}=$ production trait, $\mu=$ overall mean, $\mathrm{G}_{i}=$ fixed effect of the $i^{\text {th }}$ genotype, $\mathrm{GC}_{j}=$ fixed effect of the $j^{\text {th }}$ contemporary group, and $\mathrm{e}_{i j k}=$ random error.

Genotypes with very low frequency (less than 0.10 ) in the total sample of bulls or genetic groups showing a single genotype were not included in the analysis in order to avoid unreliable results or confounding the influence of genetic groups and genotype effects on traits of interest. The sire effect was not included in the linear model since the number of genotyped bulls which were progenies of the same sire was very small ( 8.5 on average). The possibility of confounding the influence of genotype effect and sire effect on production traits was low because of the large number of small half-sib families.

\section{Results}

We detected the $L$ and $V$ alleles of the GH1/Alu $I$ polymorphism in our sample of bulls, but although the $L L$ and $L V$ genotypes were present the VV genotype was not (Figure 1). The $A$ and $B$ alleles of the POU1F1/Hinf I polymorphism were present in our sample as the $A A, A B$ and $B B$ genotypes (Figure 2). The GH1/Alu I and POU1F1/Hinf I polymorphism allele frequencies are shown in Table 1 and the genotype frequencies in Table 2.

The GH1/Alu I polymorphism showed segregation in the Canchim, 1/2 Simmental and 1/2 Angus genetic groups. The GH1/Alu I polymorphism $L$ allele was fixed in Nellore bulls, resulting in the occurrence of the $L L$ genotype only, and its frequency was significantly higher than that of the $V$ allele in all the other genetic groups studied. Nellore animals presented a significantly higher frequency of the $L$ allele than the Canchim and 1/2 Angus groups, which in turn

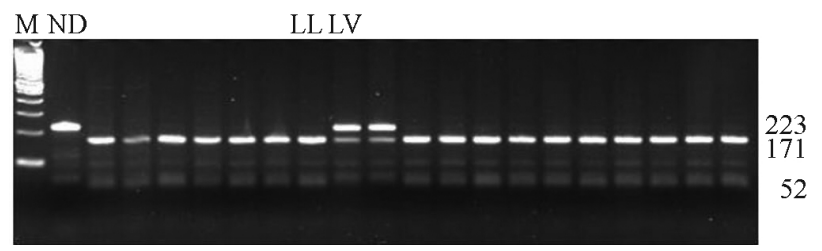

Figure 1 - Bovine $G H 1$ gene Alu I restriction fragment length polymorphisms. $\mathrm{M}=100$-bp molecular weight standard; $\mathrm{ND}=223 \mathrm{bp}$ undigested GH1 PCR product; $L L=$ genotype characterized by the presence of 171 and 52 bp restriction fragments; $L V=$ heterozygous genotype characterized by 223,171 and 52 bp fragments.

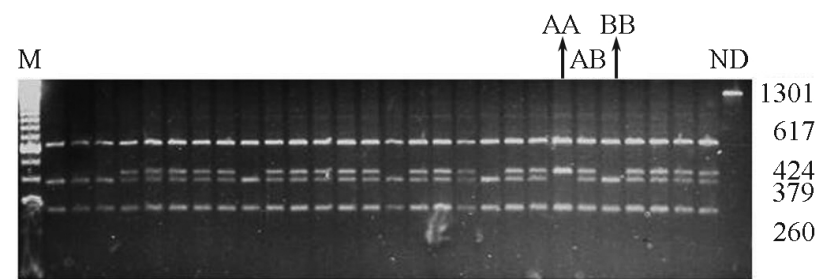

Figure 2 - Bovine $P O U 1 F 1$ gene Hinf I restriction fragment length polymorphisms. $\mathrm{M}=100$-bp molecular weight standard; $\mathrm{ND}=$ undigested POU1F1 PCR product of $1301 \mathrm{bp} ; A A=$ genotype characterized by the presence of 617,424 and $260 \mathrm{bp}$ fragments; $A B=$ heterozygous genotype characterized by $617,424,379$ and 260 bp fragments; $B B=$ genotype characterized by 617,379 and $260 \mathrm{bp}$ fragments. The small $45 \mathrm{bp}$ fragment of allele $B$ is not visible in the gel.

Table 1 - Allele frequencies of the GH1/Alu I and POU1F1/Hinf I loci for the four genetic groups and for the sample as a whole.

\begin{tabular}{lcccccc}
\hline & & \multicolumn{5}{c}{ Genetic group and allele frequency } \\
\cline { 3 - 7 } Locus & Allele & Nellore & Canchim & $1 / 2$ Simmental & $1 / 2$ Angus & Total \\
\hline GH1/Alu I & $L$ & $1.000^{\mathrm{A}, \mathrm{a}}$ & $0.933^{\mathrm{A}, \mathrm{b}}$ & $0.717^{\mathrm{A}, \mathrm{c}}$ & $0.922^{\mathrm{A}, \mathrm{b}}$ & 0.923 \\
POU1F1/Hinf I & $V$ & $0.000^{\mathrm{B}, \mathrm{c}}$ & $0.067^{\mathrm{B}, \mathrm{b}}$ & $0.283^{\mathrm{B}, \mathrm{a}}$ & $0.078^{\mathrm{B}, \mathrm{b}}$ & 0.077 \\
& $A$ & $0.897^{\mathrm{A}, \mathrm{a}}$ & $0.883^{\mathrm{A}, \mathrm{a}}$ & $0.867^{\mathrm{A}, \mathrm{a}}$ & $0.641^{\mathrm{A}, \mathrm{b}}$ & 0.731 \\
\hline
\end{tabular}

${ }^{\mathrm{A}, \mathrm{B}}$ Within the same column values with different letters are significantly different at $(\mathrm{p}<0.05) .{ }^{\mathrm{a}, \mathrm{b}, \mathrm{c}}$ Within the same lines values with different letters are significantly different at $(\mathrm{p}<0.05)$. 
Table 2 - Genotype frequencies of the GH1/Alu I and POU1F1/Hinf I loci for the four genetic groups and for the sample as a whole. The number of observations of each genotype is given in parentheses.

\begin{tabular}{lcllccc}
\hline & & \multicolumn{5}{c}{ Genetic group and allele frequency } \\
\cline { 3 - 7 } Locus & Genotype & Nellore & Canchim & $1 / 2$ Simmental & $1 / 2$ Angus & Total \\
\hline GH1/Alu I & $L L$ & $1.000(79)$ & $0.867(26)$ & $0.433(13)$ & $0.845(207)$ & $0.846(325)$ \\
& $L V$ & $0.000(0)$ & $0.133(4)$ & $0.567(17)$ & $0.155(38)$ & $0.154(59)$ \\
POU1F1/Hinf $\mathrm{I}$ & $A A$ & $0.795(63)$ & $0.800(24)$ & $0.733(22)$ & $0.295(72)$ & $0.472(181)$ \\
& $A B$ & $0.205(16)$ & $0.167(5)$ & $0.267(8)$ & $0.693(170)$ & $0.517(199)$ \\
& $B B$ & $0.000(0)$ & $0.033(1)$ & $0.000(0)$ & $0.012(3)$ & $0.011(4)$ \\
\hline
\end{tabular}

showed higher frequencies than the $1 / 2$ Simmental group. The $L L$ genotype predominated in Canchim and $1 / 2$ Angus bulls, while a higher frequency of the $L V$ genotype occurred in the $1 / 2$ Simmental group.

The POU1F1/Hinf I polymorphism segregated in all four genetic groups, with the $A$ allele showing a significantly higher frequency than the $B$ allele in all groups. The frequency of the $A$ allele was significantly higher in the Nellore, Canchim and 1/2 Simmental groups compared to the $1 / 2$ Angus group. We did not detect the POU1F1/Hinf I polymorphism $B B$ genotype in either the Nellore or $1 / 2$ Simmental bulls and its frequency was very low in the other two groups.

The least square means and standard errors of quantitative growth traits for the different genotypes of the GH1/Alu I and POU1F1/Hinf I polymorphisms are shown in Table 3, the same parameters for carcass traits being shown in Table 4.

A significant effect of the GH1/Alu I polymorphism genotypes was observed on $\mathrm{BW}_{\mathrm{END}}(\mathrm{p}=0.0241)$, average daily weight gain $(\mathrm{p}=0.0220)$ and carcass weight ( $\mathrm{p}=0.0441$ ), with the homozygous $L L$ genotype being favorable compared to the heterozygous $L V$ genotype. No significant effect was observed on $\mathrm{BW}_{0}(\mathrm{p}=0.8982), \mathrm{BW}_{1}$ $(p=0.8704)$, dressing percentage $(p=0.3496)$, ribeye area $(\mathrm{p}=0.8723)$ or backfat thickness $(\mathrm{p}=0.5898)$.

Only the $A A$ and $A B$ genotypes were considered in the comparison analysis between the POU1F1/Hinf I polymorphism genotypes and production traits. The results showed no significant effect of genotypes on the growth traits $\mathrm{BW}_{0}$ $(\mathrm{p}=0.2265), \mathrm{BW}_{1}(\mathrm{p}=0.1353), \mathrm{BW}_{\mathrm{END}}(\mathrm{p}=0.4437)$ and average daily weight gain $(\mathrm{p}=0.6831)$ or the carcass traits

Table 3 - Least square means and standard errors of the growth traits for the GH1/Alu I and POU1F1/Hinf I genotypes.

\begin{tabular}{lccccc}
\hline & & \multicolumn{4}{c}{ Growth trait $^{1}(\mathrm{~kg})$} \\
\cline { 3 - 6 } Locus & Genotype & $\mathrm{BW}_{0}$ & $\mathrm{BW}_{1}$ & $\mathrm{BW}_{\text {END }}$ & ADWG \\
\hline GHI/Alu I & $L L$ & $293.51 \pm 2.75$ & $322.13 \pm 1.94$ & $479.43 \pm 2.42^{\mathrm{a}}$ & $1.60 \pm 0.02^{\mathrm{a}}$ \\
& $L V$ & $292.90 \pm 3.69$ & $322.74 \pm 3.08$ & $468.65 \pm 3.98^{\mathrm{b}}$ & $1.53 \pm 0.03^{\mathrm{b}}$ \\
POU1F1/Hinf I & $A A$ & $281.89 \pm 2.31$ & $321.39 \pm 2.06$ & $472.72 \pm 2.80$ & $1.52 \pm 0.16$ \\
& $A B$ & $286.47 \pm 2.81$ & $325.95 \pm 2.16$ & $475.93 \pm 2.92$ & $1.51 \pm 0.17$ \\
\hline
\end{tabular}

${ }^{1} \mathrm{BW}_{0}=$ body weight at penning; $\mathrm{BW}_{1}=$ body weight at the beginning of at the start of their feedlot period; $\mathrm{BW}$ END $=$ body weight at slaughter; $\mathrm{ADWG}=$ average daily weight gain. ${ }^{\mathrm{a}, \mathrm{b}}$ Within the same columns values with different letters are significantly different at $\mathrm{p}<0.05$

Table 4 - Least square means and standard errors of the carcass traits for the GH1/Alu I and POU1F1/Hinf I genotypes.

\begin{tabular}{lccccc}
\hline & & \multicolumn{4}{c}{ Carcass $^{1}$ trait } \\
\cline { 3 - 6 } Locus & Genotype & CW $(\mathrm{kg})$ & $\mathrm{DP}(\%)$ & REA $\left(\mathrm{cm}^{2}\right)$ & $\mathrm{BT}(\mathrm{cm})$ \\
\hline GH1/Alu $\mathrm{I}$ & $L L$ & $262.17 \pm 1.60^{\mathrm{a}}$ & $55.37 \pm 0.13$ & $72.34 \pm 0.53$ & $4.83 \pm 0.12$ \\
& $L V$ & $255.28 \pm 2.55^{\mathrm{b}}$ & $55.13 \pm 0.22$ & $72.50 \pm 0.86$ & $4.71 \pm 0.19$ \\
POU1F1/Hinf $\mathrm{I}$ & $A A$ & $259.60 \pm 1.72$ & $55.36 \pm 0.12$ & $72.73 \pm 0.53$ & $4.96 \pm 0.12$ \\
& $A B$ & $262.37 \pm 1.81$ & $55.41 \pm 0.13$ & $72.52 \pm 0.55$ & $4.95 \pm 0.12$ \\
\hline
\end{tabular}

${ }^{1} \mathrm{CW}=$ carcass weight; $\mathrm{DP}=$ dressing percentage; $\mathrm{REA}=$ ribeye area; $\mathrm{BT}=$ backfat thickness. ${ }^{\mathrm{a}, \mathrm{b}}$ Within the same columns values with different letters are significantly different at $\mathrm{p}<0.05$. 
carcass weight $(p=0.2790)$, DP $(p=0.8165)$, ribeye area $(\mathrm{p}=0.7855)$ and backfat thickness $(\mathrm{p}=0.9514)$.

\section{Discussion}

The GH1/Alu I polymorphism identified by Lucy et al. (1991) consists of a cytosine to guanine exchange at codon 127 in the GH1 gene and the substitution of the amino acid leucine ( $L$ allele) by valine ( $V$ allele) to produce different forms of the growth hormone which can differ in receptor-binding efficiency and thus modify physiologic processes and produce different phenotypes.

In our study, the $L$ allele frequencies obtained were similar to results reported in the literature which showed a fixation of this allele in Zebu breeds (Kemenes et al., 1999) and its predominance in the taurine breeds Charolais (Kemenes et al., 1999), Piedmontese (Di Stasio et al., 2002), Simmental and Angus (Vasconcellos et al., 2003), with frequencies of $0.72,0.72,0.82$ and 0.77 , respectively. Silveira (2002) obtained a frequency of 0.91 for the $L$ allele in the synthetic Canchim breed.

We found significantly higher weight gain and body weight at slaughter in $L L$ animals compared to $L V$ animals. Because the $V V$ genotype was absent from our sample the type of allele interaction could not be determined. Other authors have shown that GH1/Alu I polymorphism can influence performance traits in beef cattle, with Schlee et al. (1994b) having shown that in Simmental cattle the $L V$ genotype is associated with higher weight gain while cattle with the $V V$ genotype presented better carcass scores. Regitano et al. (1999) observed a significant linear increase in the $V$ allele over four generations in a Canchim herd and suggested that this polymorphism may be associated with phenotypic traits that are subject to selection in this herd. Sartore and Di Stasio (2000) also suggested the occurrence of indirect selection for the $V$ allele in Piedmontese cattle, although in a subsequent study (Di Stasio et al., 2002) these authors found no evidence of an association between this polymorphism and growth or carcass traits in this breed. Tambasco et al. (2003) observed that $L L$ genotype Canchim x Nellore, Simmental x Nellore and Angus x Nellore crossbred cattle presented higher weight gain from birth to weaning as compared to the $L V$ genotype, although from weaning to yearling the opposite was true. In a review on the molecular genetics of beef cattle, Switonski (2002) states that most studies have shown that cattle with the $V V$ genotype show lower growth rates as compared to the other two genotypes. Due to these contradictory results, Switonski (2002) concluded that the use of the GH1/Alu I polymorphism in beef cattle selection programs is still premature.

The $A$ and $B$ alleles of the POU1F1/Hinf I polymorphism were identified by Moody et al. (1995). This polymorphism is a silent mutation $(A \rightarrow G)$ located in exon 6 of the bovine POU1F1 gene (Dierkes et al., 1998) and, therefore, probably does not cause any phenotypic variations.

The frequencies reported in the literature for the $A$ allele of the POU1F1/Hinf I polymorphism were 0.25 for Piedmontese animals (Di Stasio et al., 2002), 0.53 for Belgian Blue cattle (Renaville et al., 1997), 0.45 for Angus cattle (Moody et al., 1995), and 0.86 for the synthetic Canchim breed (Carrijo et al., 2003). We did not find allele frequencies of this polymorphism for pure Zebu breeds.

Our results for the POU1F1/Hinf I polymorphism showed no significant effect of the on growth or carcass traits, indicating that this is not a molecular marker associated with meat production in beef cattle and supporting the work of other published studies (Zwierzchowski et al., 2001; Di Stasio et al., 2002; Zhao et al., 2004). However, Renaville et al. (1997) reported that in taurine Belgian Blue cattle, POU1F1/Hinf I $B B$ animals were significantly superior to animals with the $A B$ and $A A$ genotypes in terms of body weight at 7 months of age and Carrijo et al. (2003) found that for the mixed race taurine/zebu Canchim breed the $B B$ genotype was superior to the $A B$ and $A A$ genotypes for weaning and yearling weight.

The differing results reported in the literature suggest that the GH1/Alu I and POU1F1/Hinf I polymorphisms are not directly responsible for phenotypic variations and these contradictions can be explained by differences in the linkage disequilibrium between markers and quantitative trait loci (QTL) in the various populations studied, by different epistatic interactions between the genetic bases of these populations and QTL, or even by the experimental design and statistical approach followed. However, the fact that our results for the GH1/Alu I polymorphism showed that the $L L$ genotype was superiority to the $L V$ genotype for growth and carcass traits justifies continuing studies on this polymorphism with Zebu and crossbred cattle.

\section{Acknowledgments}

The authors thank Universidade Estadual Paulista (Unesp) for providing the infrastructure for this study and Fundação de Amparo à Pesquisa do Estado de São Paulo (FAPESP) for financing the study.

\section{References}

Bodner M, Castrillo JL, Theill LE, Deerinck T, Ellisman M and Karin M (1998) The pituitary-specific transcription factor GHF-1 is a homeobox-containing protein. Cell 55:505-518.

Carrijo SM, Regitano LCA, Alencar MM and Toral FLB (2003) Influência das variantes genéticas do gene Pit1 sobre características de produção de carne em animais da raça Canchim. Proceedings of the $49^{\circ}$ Congresso Nacional de Genética, Águas de Lindóia, SP, Brasil, CD-ROM.

Chen R, Ingraham MA, Treacy MN, Albert VR, Wilson L and Rosenfeld MG (1990) Autoregulation of Pit1 gene expression mediate by two cis-active promoter elements. Nature 346:583-589. 
Curi PR and Moraes RV (1981) Associação, homogeneidade e contrastes entre proporções em tabelas contendo distribuições multinomiais. Ciên Cult 33:712-722.

Dierkes B, Kriegesmann B, Baumgartner BG and Brenig B (1998) Partial genomic structure of the bovine Pit1 gene and characterization of a Hinf I transition polymorphism in exon 6 . Anim Genet 29:405.

Di Stasio L, Sartore S and Alberta A (2002) Lack of association of $G H 1$ and $P O U 1 F 1$ gene variants with meat production traits in Piedmontese cattle. Anim Genet 33:61-64.

Goodman HM (1993) Growth hormone and metabolism. In Schreibman MP, Scanes CG, Pang PKT (eds) The Endocrinology of Growth, Development, and Metabolism in Vertebrates, Academic Press, San Diego, pp 93-115.

Gresham JD (1998) Study Guide. Real-Time ultrasound training conference. Bovine applications. University of Tennessee at Martin, 20 pp.

Kemenes PA, Regitano LCA, Rosa AJM, Packer IU, Razook AG, Figueiredo LA, Silva NA, Etchegaray MA and Coutinho LL (1999) $\kappa$-casein, $\beta$-lactoglobulin and growth hormone allele frequencies and genetic distances in Nelore, Gyr, Guzerá, Caracu, Charolais, Canchim and Santa Gertrudis Cattle. Genet Mol Biol 22:539-541.

Lin C, Lin SC, Chang CP and Rosenfeld MG (1992) Pit1 dependant expression of the receptor for growth hormone releasing factor mediates pituitary cell growth. Nature 360:765-771.

Lucy MH, Hauser SD, Eppard PJ, Krivi GG and Collier RJ (1991) Genetic polymorphism within the bovine somatotropin (bST) gene detected by polymerase chain reaction and endonuclease digestion. J Dairy Sci 74 (Suppl. 1):284.

Moody DE, Pomp D and Barendse w (1995) Restriction fragment length polymorphism in amplification products of the bovine PIT1 gene assignment of PIT1 to bovine chromosome 1. Anim Genet 26:45-47.

NRC (1996) Nutrient Requirement of Beef Cattle. National Academy Press. Washington, DC.

Owens FN, Dubeski P and Hanson CF (1993) Factor that alters the growth and development of ruminants. J Anim Sci 71:3138-3150.

Regitano LCA, Azevedo JL, Vencovsky R, Packer IU, Barbosa PF, Rosa AJM, Silva NA, Etchegaray MA and Coutinho LL (1999) Selection for breed specific growth hormone and
IGF-I alleles in a synthetic beef cattle cross, Canchim. Genet Mol Biol 22:531-537.

Renaville R, Gengler N, Parmentier I, Mortiaux F, Massart S, Bertozzi C, Burny A and Portetelle D (1997) Pit1 gene Hinf I RFLP and growth traits in double-muscled Belgian Blue cattle. J Anim Sci 75 (Suppl. 1):146.

Renaville R, Hammadi M and Portetelle D (2002) Role of the somatotropic axis in the mammalian metabolism. Dom Anim Endocrinol 23:351-360.

Sartore S and Di Stasio L (2000) Analisi genetica del locus GH (ormone della crescita) nella razza bovina Piemontese. Proceedings of the 54th Convegno Societa Italiana Delle Scienze Veterinarie (LIV). pp 411-412.

Schlee P, Graml R, Schallenberger E, Schams D, Rottmann R, Olbrich-Bludau A and Pirchner F (1994a) Growth hormone and insulin-like growth factor 1 concentrations in bulls of various growth hormone genotypes. Theor Appl Genet 88:497-500.

Schlee P, Graml R, Rottmann O and Pirchner F (1994b) Influence of growth hormone genotypes on breeding values of Simmental bulls. J Anim Breed Genet 111:253-256.

Switonski M (2002) Molecular genetics in beef cattle breeding - A review. Anim. Sci Pap Rep 20:7-18.

Tambasco DD, Paz CCP, Tambasco-Studart MD, Pereira AP, Alencar MM, Freitas AR, Coutinho LL, Packer IU and Regitano LCA (2003) Candidate genes for growth traits in beef cattle crosses Bos taurus x Bos indicus. J Anim Breed Genet 120:51-56.

Vasconcellos LPMK, Tambasco DD, Pereira AP, Coutinho LL, Regitano LCA (2003) Genetic characterization of Aberdeen Angus cattle using molecular markers. Genet Mol Biol 26:133-137.

Zhao Q, Davis ME, Hines HC (2004) Associations of polymorphisms in the Pit-1 gene with growth and carcass traits in Angus beef cattle. J Anim Sci 82:2229-2233.

Zwierzchowski L, Oprzadek J, Dymnicki P and Dzierzbicki P (2001) An association of growth hormone, $\kappa$-casein, $\beta$-lactoglobulin, leptin and Pit1 loci with growth rate and carcass traits in beef cattle. Anim Sci Pap Rep 19:65-78.

Weir BS (1996) Genetic data analysis:Methods for Discrete Population Genetic Data. 2nd ed. Sinauer Associates, Sunderland, MA, USA, 445 pp.

Associate Editor: Pedro Franklin Barbosa 